\title{
A trial of prophylactic replacement therapy in haemophilia and Christmas disease
}

\author{
D. M. RAMSAY' AND A. C. PARKER \\ From the Department of Haematology, Royal Infirmary of Edinburgh, Scotland
}

SYNOPSIS A trial of prophylactic replacement therapy in low dosage once a week is described in two patients with classical haemophilia and one patient with Christmas disease, using concentrates of factor VIII and factor IX respectively. The clinical effectiveness and complications of the therapy are assessed and discussed. It was concluded that the patient suffering from Christmas disease showed both objective and subjective improvement while on prophylaxis and merited further study. Neither of the patients with haemophilia showed objective evidence of improvement, but both stated that they felt fitter and more able to lead a normal life while on the trial.

Prophylaxis of bleeding episodes in haemophilia with factor VIII concentrates is well documented (Robinson, Tittley, and Smiley, 1967; Hirschmann, Itscoitz, and Shulman, 1970; Nilsson, Blömbach, and Ahlberg, 1970; Van Creveld, 1971). Shanbrom and Thelin (1969) have shown that prophylaxis with factor VIII concentrate once a week is effective in preventing bleeds provided that the level of factor VIII is raised to $100 \%$ on each occasion. This trial sought to show whether any residual effects from the infusion of six packs of cryoprecipitate once a week would reduce the incidence of bleeds over a ninemonth period even though factor VIII levels fall rapidly. Hirschmann et al (1970) have shown that after infusion of cryoprecipitate from 2-4 litres of plasma the factor VIII level of the patient's plasma falls to $2 \%$ after 36 hours.

The patient with Christmas disease was also given once a week low-dose prophylaxis using a new factor II, IX, and X concentrate which was prepared from acid-citrate-dextrose blood (Smith and Robinson, 1970). Suitable concentrates containing high levels of factor IX have been difficult and expensive to prepare and, as far as is known, this is the first described prophylactic trial using this factor II, IX, and X concentrate. The use of such products in bleeding episodes (Haanen, McShine, and Kunst, 1969; Dike, Bidwell, and Rizza, 1972) and for covering dental extractions (Van Creveld and Buchner, 1970) is, however, well attested.

${ }^{1}$ Dr D. M. Ramsay, Department of Haematology, Royal Infirmary, Edinburgh EH3 9YW, Scotland

Received for publication 5 February 1973.

\section{Materials and Methods}

The two severe haemophiliacs (plasma factor VIII level $<1 \%$, H.S. and A.C., and one patient, H.M., with severe Christmas disease (plasma factor IX level $<1 \%$ ) were selected for prophylactic therapy. None of the patients showed inhibitors. Assays were one-stage methods based on the partial thromboplastin time (Hardisty and McPherson, 1962), and utilized factor-VIII- or factor-IX-deficient plasma as substrate. Inhibitor assays were also based on the partial thromboplastin time, this parameter being measured on test and control plasma and on a mixture of the two before and after incubation for one hour at $37^{\circ} \mathrm{C}$ (Roberts, Scales, Madison, Webster, and Penick, 1965).

The three patients participated in a control period from April 1970 till January 1971 in which replacement therapy with fresh frozen plasma or antihaemophilic globulin (AHG) was used 'on demand' to treat bleeding episodes and in a trial period from April 1971 till January 1972 in which prophylaxis with six packs of cryoprecipitate was given once a week to the haemophiliacs and two vials of factor II, IX, and $X$ concentrate were given to the patient with Christmas disease. Cryoprecipitate was prepared by the method of Pool, Hershgold, and Pappenhagen (1964), using $200 \mathrm{ml}$ of plasma for 1 unit AHG concentrate by a modification (Blombäch, Blombäch, Jorpes, and Nilsson, 1960) of Cohn fractionation of plasma (Cohn, Strong, Hughes, Mulford, Ashworth, Metin, and Taylor, 1946). The factor II, IX, and $\mathrm{X}$ concentrate was obtained from the supernatant of 
Cohn fraction 1 by ion exchange chromatography on a DEAE cellulose column (Smith and Robinson, 1970). The latter material is supplied freeze-dried in vials and is reconstituted with $10 \mathrm{ml}$ of sterile distilled water immediately before intravenous injection. One $\mathrm{ml}$ of the injection material contains $25-40$ units of factor IX, a unit being the equivalent quantity of factor IX in $1 \mathrm{ml}$ of fresh plasma. One vial of concentrate is thus obtained from 2-3 unit donations of blood.

\section{Patients}

The patient studied, H.S., aged 29, owned his own photographic business and frequently had a busy schedule and long, tiring hours. Bleeding episodes had necessitated his attending hospital for treatment once every two to three weeks and he had moderate haemarthritic changes in the joints both clinically and radiologically although very little joint deformity and disability were present when free from bleeding activity. Tests for serum hepatitis ( $\mathrm{SH}$ )-associated antigen and antibody by counter-immunoelectroosmophoresis (Prince and Burke, 1970; Das, Hopkins, Cash, and Cumming, 1971) were negative at the start of the trial.

A.C., aged 17, had been employed as a clerk in a lawyer's office since leaving school in 1970. He was also a frequent hospital attender for bleeding episodes and, although no joint deformities were present, he also showed moderated arthritic changes of the knee joints both clinically and radiologically. Tests for SH-associated antigen became positive between the control and trial periods but he has never shown clinical jaundice or hepatomegaly though liver function tests have been disturbed with serum aminotransferase (SGPT) levels up to 220 GPT units/ml (normal range 10-35 GPT units/ml).

H.M., aged 25, was currently self employed as a free-lance commercial artist. Clinical stigmata of the disease included moderate joint deformities and radiologically there were moderately severe arthritic changes present. Clinical hepatitis with SH antigen positive occurred between the control and trial periods but at the time of starting prophylaxis he was SH antigen and antibody negative and liver function tests were normal.

\section{Assessment of Need for Prophylaxis}

In each case the need for prophylactic therapy was primarily assessed in the light of the number of? bleeding episodes of sufficient severity to require replacement. (The incidence of vague joint aches and the incidence and severity of bleeds not requiring replacement therapy were too variable and sub $\mathbb{Q}$ jective to be included in the trial.) Whether thes episode was 'spontaneous' or secondary to a clearly defined traumatic incident was only considered in the patient with Christmas disease.

Other factors considered were the number of days between the prophylactic infusion and the bleedings episode, ie, the time relationship of the episode tô prophylaxis; the number of working days losts through disability caused by bleeding episodes; the progression of arthritic changes in joints observed radiologically; the amount of therapeutic materia $B$ used during the trial and control periods and the equivalent number of blood donations represented the rise in factor VIII or factor IX levels in responseto the prophylactic dose; the incidence, nature, ande severity of allergic reactions to the products (asi fresh frozen plasma was used for treating both diseases before April 1971, reactions could not be compared with those in the control period). Tests of liver function and for $\mathrm{SH}$-associated antigen and antibody were performed every two weeks.

\section{Results}

Bleeding incidents requiring replacement therapy i control and trial periods were 18 and 25 respectivel for patient H.S., 24 and 12 for patient A.C., and nine as against four for H.M. In the last patient, all nine bleeds in the control period were spontaneous but three out of the four bleeds during the trial were associated with definite trauma.

The day on which bleeding first occurred after the prophylactic infusion is shown in table I. The two haemophiliacs showed a random distribution of sucR. episodes but the Christmas disease patient never bled on the three days immediately following the prophyo lactic infusion.

Patient H.S. lost two days from work during the్ trial as compared with 10 days in the control period

\begin{tabular}{|c|c|c|c|c|c|c|c|}
\hline \multirow[t]{2}{*}{ Subjects } & \multicolumn{6}{|c|}{ Number of Bleeding Episodes on Successive Days following Prophylactic Infusion } & \multirow[t]{2}{*}{ Total Bleeding Episodes } \\
\hline & Ist Day & 2nd Day & 3rd Day & 4th Day & 5th Day & 6th Day & \\
\hline $\begin{array}{l}\text { H.S. } \\
\text { A.C. } \\
\text { H.M. }\end{array}$ & $\begin{array}{l}7 \\
0 \\
0\end{array}$ & $\begin{array}{l}1 \\
2 \\
0\end{array}$ & $\begin{array}{l}4 \\
6 \\
0\end{array}$ & $\begin{array}{l}5 \\
2 \\
1\end{array}$ & $\begin{array}{l}5 \\
1 \\
1\end{array}$ & $\begin{array}{l}3 \\
1 \\
2\end{array}$ & $\begin{array}{r}25 \\
12 \\
4\end{array}$ \\
\hline
\end{tabular}

Table I Time relationship of bleeding episodes to prophylactic dose 


\begin{tabular}{|c|c|c|c|c|c|c|c|}
\hline \multirow[t]{3}{*}{ Subjects } & \multicolumn{5}{|l|}{ During Trial } & \multicolumn{2}{|l|}{ Control Period } \\
\hline & \multirow[t]{2}{*}{ Prophylactic Therapy } & \multirow[t]{2}{*}{ Emergency Therapy } & \multicolumn{3}{|c|}{ Equivalent No. of Donors } & \multirow[t]{2}{*}{ Total Amount } & \multirow{2}{*}{$\begin{array}{l}\text { Total Equivalent } \\
\text { No. of Donors }\end{array}$} \\
\hline & & & Prophylaxis & Emergency & Total & & \\
\hline H.S. & 240 packs cryoprecipitate ${ }^{1}$ & $\begin{array}{l}184 \text { packs cryoprecipitate } \\
+9 \text { units } \mathrm{AHG}^{3}\end{array}$ & 240 & 238 & 478 & \multirow{3}{*}{$\begin{array}{l}11 \text { litres fresh frozen plasma } \\
+47 \text { packs cryoprecipitate } \\
21 \text { litres fresh frozen plasma } \\
+3 \text { units AHG } \\
+58 \text { packs cryoprecipitate } \\
\text { 13.5 litres fresh frozen plasma }\end{array}$} & 91 \\
\hline A.C. & 240 packs cryoprecipitate & $\begin{array}{l}93 \text { packs cryoprecipitate } \\
+1 \text { unit } \mathrm{AHG}\end{array}$ & 240 & 99 & 339 & & 160 \\
\hline H.M. & $\begin{array}{l}80 \text { vials II } \\
\text { IX, X complex }\end{array}$ & $\begin{array}{l}9 \text { vials II } \\
\text { IX, X complex }\end{array}$ & 240 & 27 & 167 & & 54 \\
\hline
\end{tabular}

Table II Amount of factor VIII or factor IX required during the trial and control periods

${ }^{1}$ One pack of cryoprecipitate is obtained from the plasma from one donor.

${ }^{2}$ One litre of fresh frozen plasma is obtained from plasma from four donors.

${ }^{3}$ One unit of AHG (antihaemophilic globulin) is obtained from the plasma from six donors.

'One vial of II IX X complex is obtained from the plasma from three donors.

and A.C. lost no days as compared with 20 days in the control period. The Christmas disease patient, H.M. also lost no time from his work during the trial as compared with seven days in the control period.

In general radiographs of the joints were available in late 1969 and at the end of the trial in early 1972. In the Christmas disease patient, apart from a slight deterioration in the proximal right tibial articular surface, the knee joints showed no deterioration.

In both haemophiliacs there were moderate progressive destructive changes in both knee joints, and in H.S. a slight deterioration in the left ankle joint.

Table II shows the amounts of factor VIII and factor IX concentrate required for prophylaxis and emergency treatment during the trial and compares this with the amount used during the control period.

Factor VIII assays, before and after the infusion of six packs of cryoprecipitate in the first haemophiliac, H.S., showed rises of $15 \%, 21 \%$, and $20 \%$ on three separate occasions during the trial. The other haemophiliac was positive for $\mathbf{S H}$-associated antigen throughout the trial and no assays were done in that period. Infusions of five packs of cryoprecipitate on six occasions in February and March of 1971 showed an average rise of $14.5 \%$ in the factor VIII level.

The Christmas disease patient, H.M., assayed on three separate occasions during the trial, showed rises of $6 \%, 10 \%$, and $15 \%$ in factor IX level.

Because of the patient's good response to prophylactic therapy, serial assays were carried out daily following the infusion of two vials of factor II, IX, X concentrate in March 1972. The results of these assays are shown in figure 1.

None of the three patients developed a detectable inhibitor to their deficient factor by tests in vitro. The consistent rise in vivo of factors VIII or IX in response to transfusion therapy is corroborative evidence of this.

Both haemophilic patients have had several mild urticarial reactions to cryoprecipitate and H.S. has had a febrile reaction on two occasions. Symptoms were controlled by the intravenous injection of chlorpheniramine and no severe reactions necessitating the use of hydrocortisone (Ahrons, GlavindKristensen, Drachmann, and Kissmeyer-Nielsen, 1970) were encountered. Reactions to fresh frozen plasma, which was used in the control period before cryoprecipitate was available, were more frequent even though prophylactic chlorpheniramine was given by injection immediately beforehand.

The factor II, IX, X concentrate never caused a reaction in the patient with Christmas disease and chlorpheniramine was not required. Reactions to

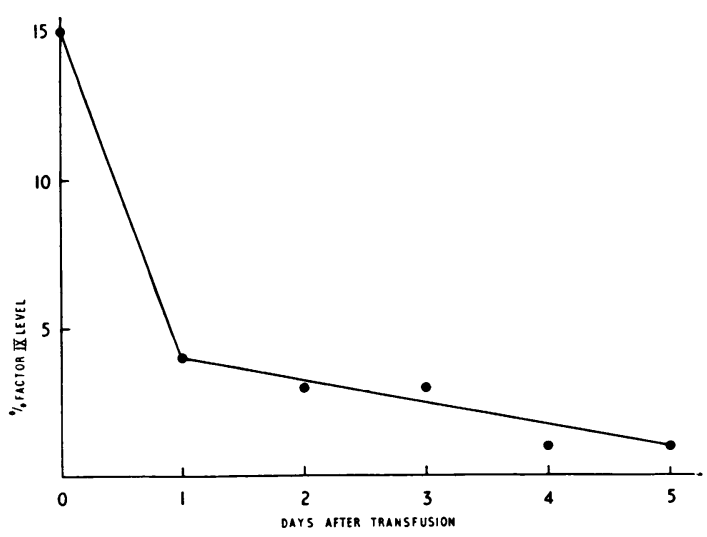

Fig 1 Factor levels on successive days following prophylactic infusion of two vials of II IX X complement in patient H.M. 


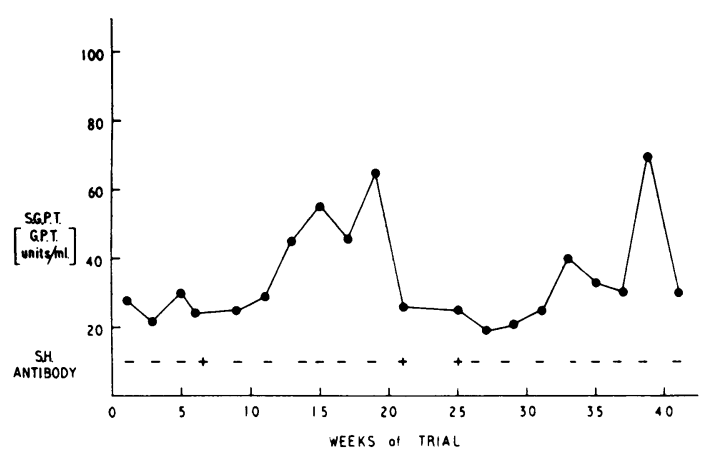

Fig 2 Serum GPT and serum hepatitis-associated antibody in subject H.S. The antibody is graded as \pm if present in neat serum, + if present in serum concentrated $\times 5$, and - if not detected.

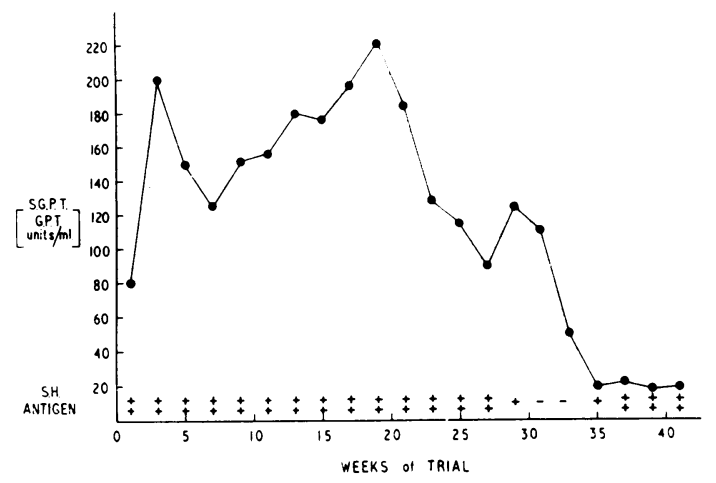

Fig 3 Serum GPT and serum-hepatitis-associated antigen in subject A.C. The antigen is graded as + if present in neat serum, + if present in serum concentrated $\times 5$, and - if not detected.

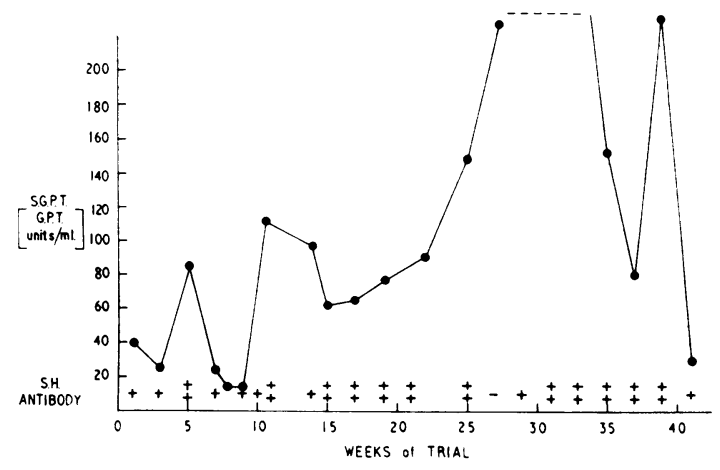

Fig 4 Serum GPT and serum hepatitis-associated antibody in subject H.M. The antibody is graded as + if present in neat serum, + if present in serum concentrated $\times 5$, and - if not detected. fresh frozen plasma in the past had been frequent and sometimes severe, and prophylactic chlorpheniramine had always been necessary.

The presence of SH antigen or antibody and the serum SGPT as a parameter of active liver damage has been plotted in graphic form in each of the patients in figures $2-4$. None of the patients experienced clinical jaundice during the trial and serum bilirubin levels were always below $1.2 \mathrm{mg} / 100 \mathrm{ml}$ (normal value $<1 \mathrm{mg} / 100 \mathrm{ml}$ ). Serum alkaline phosphatase levels (normal range 3-13 King Armstrong units $/ 100 \mathrm{ml}$ ) were raised transiently to $32 \mathrm{King}$ Armstrong units $/ 100 \mathrm{ml}$ in the patient with Christmas disease from the 29th to the 34th week of the trial when SGPT levels were markedly elevated.

\section{Discussion}

Despite the increased wellbeing of the two haemophilic patients and their enthusiasm to continue the regime, there was no objective evidence that weekly prophylaxis with six packs of cryoprecipitate was of clinical value. The conclusions are supported by the finding of a random incidence of bleeding episodes on the days following prophylaxis and are consistent with the results of other workers who have shown that prophylactic infusions, giving a factor VIII level of approximately $20 \%$, are required three to four times a week to prevent bleeding episodes. Shanbrom and Thelin (1970) have shown that once weekly prophylaxis would prevent bleeding episodes in severe haemophilia but the factor VIII level had to be raised to $100 \%$. If the levels attained were lower, reduced though significant bleeds occurred.

In subject H.M., with Christmas disease, bleeding episodes were reduced by approximately half which may not be significant. However, only one spontaneous bleeding episode occurred and all of the bleeds were confined to the three days immediately before the next prophylactic infusion. His left shoulder joint, which developed several spontaneous haemarthroses during the control period in 1970, gave no trouble during the trial. Bleeding episodes in the latter period were clearly related to trauma such as falling on his wrist on one occasion or moving heavy furniture on another.

The greater degree of protection afforded by factor IX concentrate once weekly in the Christmas disease patient than by cryoprecipitate in the haemophiliacs may be related to its longer half-life demonstrated by the serial assays following prophylaxis on one occasion (fig 1). Preliminary results with this concentrate are encouraging, especially since a great deal of treatment was required in the first four months of 1971 before the start of the trial (unpublished findings). Also, since factor IX levels fell to less than 
$1 \%$ only after four days, it was concluded that twice weekly prophylaxis with one vial of factor II, IX, X concentrate might have been of more value than two vials once a week, and this has been planned to commence.

Complications of prophylactic therapy were few and were those which would be expected to occur in recurrent courses of therapy. None of the patients developed detectable inhibitors to their deficient factor despite the large amounts of therapeutic material used. It is our experience that the development of inhibitors is related to factors intrinsic to the patient rather than to the amount of therapy, and is in agreement with the findings of Ikkala and Simonen (1971) who showed that inhibitors usually develop within 90 days of exposure to transfusion in classical haemophilia or not at all. Allergic reactions to the products occurred occasionally but were mild and responded well to the administration of chlorpheniramine.

One serious complication of the continual use of human plasma products was the persistence of SHassociated antigen in subject A.C. and SH antibody in H.M. Liver dysfunction, as evidenced by raised SGPT levels, was associated with both antigen and antibody but neither patient developed jaundice during the trial. The persistence of SH antigen or antibody is well recognized in haemophiliacs and may be related to repeated immunization of antigen or, in the case of SH antibody, to non-specific stimulation by antigenically similar substances. The results of concurrent liver function and SH antigen/ antibody tests demonstrated that active damage to the liver was associated with the presence of either antigen or antibody and that a temporary weakening or absence of the antibody coincided with an active phase of liver damage.

The authors wish to thank Dr R. A. Cumming, Director of the Regional Blood Transfusion Service, who supplied the material for the trial, and Dr T. A.S. Buist, who read the radiographs. We are also indebted to Dr R. H. Swain, University Bacteriology Department, and Dr P. C. Das, Blood Transfusion Service, who undertook SH antigen and antibody testing, to the staff of the Clinical Chemistry Department who assisted with liver function tests, and to Mr G. Allan, FIMLT, and Mr E. Robertson, FIMLT, who carried out the factor assays. Our thanks are also due to Dr S. H. Davies, chief of the
Haematology Department, who gave invaluable advice and assistance in preparing the paper.

\section{References}

Ahrons, S., Glavind-Kristensen, S., Drachmann, O., and KissmeyerNielsen, F. (1970). Severe reactions after cryoprecipitated human factor VIII. Vox Sang. (Basel), 18, 182-184.

Blombäch, M., Blombäch, B., Jorpes, E., and Nilsson, I. M. (1960). On the preparation of human antihaemophilic globulin. In Proceedings of the Seventh Congress of the European Society of Haematology, London, Part II, p. 587. Karger, Basle.

Cohn, E. J., Strong, L. E., Hughes, W. L., Jr., Mulford, D. J., Ashworth, J. N., Metin, M., and Taylor, H. L. (1946). Preparation and properties of serum and plasma proteins. IV. A system for the separation into fractions of the protein and lipoprotein components of biological tissues and fluids. J. Amer. chem. Soc., 68, 459-475.

Das, P. C., Hopkins, R., Cash, J. D., and Cumming, R. A. (1971). 'Rapid identification of hepatitis associated antigen and antibody by counter-immunoelectroosmophoresis.' Brit. J. Haemat., 21, 673-676.

Dike, G. W. R., Bidwell, E., and Rizza, C. R. (1972). The preparation and clinical use of a new concentrate containing factor IX, prothrombin and factor $X$ and of a separate concentrate containing factor VII. Brit. J. Haemat., 22, 469-490.

Haanen, C., McShine, R. L., and Kunst, A. (1969). Preparation and clinical use of factor IX concentrate. Vox Sang. (Basel), 16, 398-411.

Hardisty, R. M., and McPherson, J. C. (1962). A one-stage factor VIII (antihaemophilic globulin) assay and its use on venous and capillary plasma. Thrombos. Diathes. haemorrh. (Stuttg.), 7, 215.

Hirschmann, R. J., Itscoitz, S. B., and Shulman, N. R. (1970). Prophylactic treatment of factor VIII deficiency. Blood, 35, 189-194.

Ikkala, E., and Simonen, O. (1971). Factor VIII inhibitors and the use of blood products in patients with haemophilia A. Scand. J. Haemat., 8, 16-20.

Kasper, C. K., Dietrich, S. L., and Rapaport, S. I. (1968). Haemophilia prophylaxis with AHF Concentrate. (Abstr.) In XII Congress, International Society of Haematology, New York, p. 312.

Nilsson, 1. M., Blombäch, M., and Ahlberg, A. (1970). Our experience in Sweden with prophylaxis on haemophilia. In The Hemophiliac and His World: Proceedings of the 5th World Federation of Hemophilia, Montreal, 1968, by R. Gourdeau (Bibl. haemat., no. 34), pp. 111-124. Karger, Basle and New York.

Pool, J. G., Hershgold, E. J., and Pappenhagen, A. R. (1964). High potency antihaemophilic factor concentrate prepared from cryoglobulin precipitate. Nature (Lond.), 203, 312.

Prince, M. A., and Burke, K. (1970). Serum hepatitis antigen (S.H.) rapid detection by high voltage immunoelectroosmophoresis. Science, 169, 593-595.

Roberts, H. R., Scales, M. B., Madison, J. T., Webster, W. P., and Penick, G. D. (1965). A clinical and experimental study of acquired inhibitors to factor VIII. Blood, 26, 805-818.

Robinson, P. M., Tittley, P., and Smiley, R. K. (1967). Prophylactic therapy in classical hemophilia. Canad. med. Ass. J., 97, 559-561.

Shanbrom, E., and Thelin, G. M. (1969). Experimental prophylaxis of severe hemophilia with a factor VIII concentrate. J. Amer. med. Ass., 208, 1853-1856.

Smith, J. K., and Robinson, S. M. (1970). Concentrates of human coagulation factors II IX and X from Cohn supernatant 1 . In $I I$ Congress International Society on Thrombosis and Haemostasis, Oslo, 1971, p. 56.

Van Creveld, S. (1971). Prophylaxis of joint hemorrhages in hemophilia. Acta Haemat. (Basel), 45, 120-127.

Van Creveld, S., and Buchner, R. (1970). Dental extractions and the use of Christmas factor concentrate in cases of haemophilia $B$. Vox Sang. (Basel), 18, 441-449. 